3. Хамітов Н.В. Духовність. Енциклопедія сучасної України. URL: http://esu.com.ua/ search_articles.php?id=19642

4. Лавриченко Н. Категорії «соціальність», «духовність» i «моральність» в сучасній педагогічній науці. Шлях освіти. № 1. C. $7-11$.

5. Нерсесянц В.С. Юриспруденция. Введение в курс общей теории права и государства. Москва: Норма, Инфра-М, 1998. 288 с.

6. Domingo R. Spiritual Influences on the Law. The Canopy Forum, Atlanta, 8 October 2019. URL: https://www.academia.edu/40836171/ Spiritual_Influences_on_the_Law

DOI https://doi.org/10.30525/978-9934-588-92-1-20

\title{
МОДЕЛІ НАГЛЯДУ ЗА ОРГАНАМИ МІСЦЕВОГО САМОВРЯДУВАННЯ У ДЕРЖАВАХ-ЧЛЕНАХ ЄВРОПЕЙСЬКОГО СОЮЗУ
}

\author{
Гришко Л. М. \\ кандидат юридичних наук, старший науковий співробітник \\ Науково-дослідного інституту державного будівництва \\ та місиевого самоврядування \\ Національної академії правових наук України \\ м. Харків, Украӥна
}

Зарубіжний досвід впровадження положень Європейської хартії місцевого самоврядування 1985 р. щодо нагляду за органами місцевого самоврядування представляє значний інтерес для України. Відповідно до положень ст. 8 Свропейської хартії місцевого самоврядування 1985 р., нагляд може здійснюватися лише відповідно до процедур та у випадках, передбачених конституцією або законами, 3 додержанням принципу пропорційності, обмежуючись питанням законності дій, а не їх доцільності. Нагляд за доцільністю допускається лише щодо делегованих повноважень [1].

Контроль/нагляд за діяльністю органів місцевого самоврядування в теорії конституційного права розрізняють за різними критеріями. За часом проведення виокремлюють попередній, поточний, остаточний $[2,60]$. Саме цей критерій класифікації беруть до уваги при характеристиці моделей нагляду за органами місцевого самоврядування. 
Виокремлюють наступні моделі нагляду: французьку (латинську), німецьку, скандинавську, постсоціалістичну [3].

Французька модель діє у Бельгії, Італії, Іспанії, Люксембургу. Нагляд за місцевим самоврядуванням обмежений i охоплює лише питання законності. Наглядові органи не здійснюють перевірки доцільності того чи іншого рішення, оскільки це питання поза межами їх компетенції. Так, в Італії нагляд за місцевим самоврядуванням обмежений і охоплює лише питання законності. Як і інші держави за французьким прикладом, Італія також пережила довгу історію надзвичайно потужного адміністративного нагляду за місцевими органами самоврядування. Сьогодні нагляд здійснюється префектами та урядовими регіональними уповноваженими. Ці органи здійснюють подальший контроль, який, на думку Конституційного суду Італії, завжди повинен відповідати принципу пропорційності щодо виявленого порушення. Органи нагляду не можуть скасувати незаконні рішення або зупинити їх виконання, однак вони можуть ініціювати процедури контролю з боку центральних адміністративних органів. Таким чином, колишня система нагляду, яка грунтувалася на санкціях, була замінена на систему співпраці [3, с. 8-9].

Подібна ситуація і в Іспанії, де наглядовий орган (урядовий уповноважений) не наділений повноваженнями скасовувати акти органів місцевого самоврядування, а може лише призупинити їх дію 3 подальшим зверненням до Конституційного або адміністративного суду. Однак, у виняткових випадках, якщо місцевий орган неодноразово/ систематично в супереч закону відмовляється приймати рішення, яке $\epsilon$ обов'язковим згідно із законом, урядовий уповноважений може вжити необхідних заходів самостійно. Нагляд в Іспанії теж обмежений питаннями законності. Крім того, держава захищає статути автономій, як частину законодавства держави [3, с. 9-10].Таким чином, нагляд за законністю включає нагляд за додержанням відповідних статутів.

У Німеччині та Австрії діє, звичайно німецька модель. У тлумаченні Федерального конституційного суду, державний нагляд за місцевими органами самоврядування означає «природний противагу правам громад», і він здійснюється лише для захисту суспільних інтересів. У зв'язку з цим Конституційний суд Баварії наголосив, що цей нагляд не повинен перетворюватися на втручання. Відповідно до Закону про муніципалітети, державний нагляд означає підтримку, захист та допомогу громадам виконувати свої завдання належним чином. Юридичний нагляд за місцевими органами самоврядування здійснюють органи державного управління Земель [3, с. 11-12].

Нагляд у випадках делегованих повноважень враховує не тільки наступний нагляд за законністю, але і попередній нагляд за доцільністю 
прийнятих рішень, який передбачає істотніше втручання у сферу самоврядування. Юридичний нагляд однаково охоплює превентивні, коригувальні (на підтримку місцевих органів) та примусові заходи. У німецькій системі рішення можуть бути скасовані лише адміністративним, земельним судами або Федеральним конституційним судом [3, с. 12]. Наприклад, відповідно до Муніципального кодексу Землі Північна Рейн-Вестфалія, наглядовий орган держави приймає рішення щодо прикордонних спорів муніципалітетів (§ 16). Крім того, муніципалітет зобов'язаний повідомити контролюючий орган, до початку впровадження певних рішень муніципалітетом щодо окремих метеріально-фінансових питань (заснування або значне розширення діяльності муніципальної компанії або суттєва зміна цілей іії діяльності та ін.) Повідомлення повинно містити інформацію про дотримання законодавчих вимог (§ 115) [4].

Скандинавська модель представлена в Швеції, Фінляндії, Данії, Нідерландах. У Швеції нагляд за місцевим самоврядуванням здійснюють децентралізовані державні органи, так звані адміністративні органи, що працюють на регіональному рівні, гарантуючи законність місцевого самоврядування. Якщо вони вважають, що місцеве рішення порушує закон, вони можуть подати апеляцію до Адміністративного суду або, в деяких випадках, накласти штраф [3, с. 13].

Фінська система надзвичайно зосереджена на виконанні положень ст. 8 Європейської хартії місцевего самоврядування. Після вступу до СС контроль центрального уряду над місцевими органами самоврядування різко зменшився. Компетенція уряду була істотно обмежена і тепер зводиться практично до моніторингової діяльністю [3, с. 14].

Нагляд в Данії здійснюють 5 регіональних та 15 окружних префектів (Statsforvaltninsdirektor), яких призначає уряд. Вони можуть скасувати незаконні рішення або накласти штрафи на відповідний представницький орган 3 метою забезпечення наглядових заходів. Органи місцевого самоврядування можуть звернутися до Міністерства внутрішніх справ 3 питань апеляції на дії префектів [3, с. 14]. Крім того, Зведений закон Данії «Про місцевий уряд» від 24 жовтня 2006 р. у ст. 63, передбачає, що відповідний міністр може надавати коментарі щодо законності дій або бездіяльності місцевого уряду. Міністр внутрішніх справ та охорони здоров'я визначає форму річного бюджету, багаторічного бюджетного прогнозу та бухгалтерського обліку місцевого уряду (ст. 57) [5].

Остання модель - постсоціалістична діє в Польщі, Чехії, Словенії, Словаччині, Румунії та Естонії. Система органів нагляду істотно різниться. У Польщі вся діяльність органів місцевого самоврядування підлягає нагляду, який здійснюється прем'єр-міністром, воєводами та, 90 
що стосується фінансових питань, регіональними аудиторськими судами. Юридичний нагляд за місцевими органами самоврядування у Словаччині здійснюють суди та прокурори. Сфера власних повноважень місцевого самоврядування в Чехії перебуває під наглядом Міністерства внутрішніх справ, тоді як нагляд за діяльністю в рамках делегованих повноважень, здійснюється регіональними управліннями. У Румунії діють префекти, які $€$ представниками уряду на місцевому рівні. Між префектами та органами місцевого самоврядування відсутнє підпорядкування. Однак, якщо префект визнає акт округу чи місцевої ради незаконним, він може оскаржити його в Адміністративному суді. В Естонії нагляд за діяльністю місцевого самоврядування здійснюють три органи: губернатори графств (maavanemad), Державна контрольна служба (Riigikontroll) та канцлер юстиції (Õiguskantsler) [3, с. 16-17].

Згідно зі ст. 140 Конституції Республіки Словенія, органи державної влади контролюють належне та компетентне управління місцевими справами, а не тільки контроль за законністю місцевих рішень. Наглядовий орган не має права скасовувати або змінювати рішення, якщо це відноситься до повноважень Конституційного суду (щодо нормативних актів) або Адміністративного суду (щодо актів індивідуального характеру) [3, с. 18]. Крім того, в межах муніципалітету діє Наглядова рада, як муніципальних контрольний орган. Відповідно до ст. 32 Закону Словенії «Про місцеве самоврядування», наглядова рада $\epsilon$ найвищим органом контролю за публічними витратами муніципалітету. Якщо Наглядова рада в межах своєї компетенції виявить серйозне порушення норм чи функціювання муніципалітету, вона зобов'язана повідомити про це відповідне міністерство та Рахунковий суд Республіки Словенія (Računsko sodišče Republike Slovenije) [6].

Отже, нагляд охоплює низку обмежених повноважень органу вищого рівня 3 метою захисту законності та суспільних інтересів на випадок, якщо місцевий орган вживає незаконних заходів або виходить за межі своєї компетенції, встановленої законом. При цьому система органів нагляду/контролю істотно різниться, як і зміст нагляду. Система нагляду, яка грунтувалася на санкціях, поступово замінюється на систему співпраці.

\section{Література:}

1. Європейська хартія Про місцеве самоврядування та пояснювальна доповідь. Конгрес місцевих і регіональних органів Ради Європи, 2012. 56 с. URL: https://samoorg.com.ua/wp-content/uploads/ 2008/04/YEHMS.pdf 
2. Смоляр О. А. Державний контроль у сфері місцевого самоврядування: особливості правового регулювання. Проблеми законності. 2015. Вип. 129. С. 59-68. URL: http://nbuv.gov.ua/ UJRN/Pz_2015_129_9

3. EMESE PÁL Models of Legal Supervision over Local SelfGovernments in Continental Europe (Excluding France). Pécs Journal of International and European Law. 2018/II p. 6-20. URL: http://ceere.eu/pjiel/wp-content/uploads/2019/03/emese-1.pdf

4. Gemeindeordnung für das Land Nordrhein-Westfalen (GO NRW).URL: https://recht.nrw.de/lmi/owa/br_text_anzeigen?v_id=23200 21205103438063\#FV

5. Про місцевий уряд: зведений закон Данії від 24 жовтня 2006 р. № 1060. URL: http://www.csi.org.ua/www/?p=2414

6. Zakon o lokalni samoupravi. Uradni list RS, št.94/07 (uradno prečiščeno besedilo) URL: http://pisrs.si/Pis.web/pregledPredpisa?id= ZAKO307

DOI https://doi.org/10.30525/978-9934-588-92-1-21

\title{
ПРИНЦИП ЗАГАЛЬНОГО ВИБОРЧОГО ПРАВА: МІЖНАРОДНІ СТАНДАРТИ ТА ПЕРСПЕКТИВИ ЗАКОНОДАВЧОЇ РЕАЛІЗАЦЇ̈ В УКРАЇНІ
}

\author{
Гудзь Л. В. \\ кандидат юридичних наук, доцент, \\ доцент кафедри конституційного і муніципального права \\ юридичного факультету \\ Харківського національного університету імені В. Н. Каразіна \\ м. Харків, Україна
}

Принцип загального виборчого права означає, що громадяни можуть обирати і бути обраними після досягнення відповідного віку незалежно від статі, кольору шкіри, національності, ставлення до релігії і переконань, а також, як правило, незалежно від майнового i посадового становища. Значення цього принципу для державотворення ще на початку XX ст. яскраво підкреслив відомий учений-правник Б. Кістяківський, який говорив: «Немає нічого, що такою мірою забезпечувало б державну єдність і національну солідарність, як 